\title{
Pengembangan Sistem Pendeteksi Lokasi Titik Api dalam Ruangan Terbatas
}

\author{
Dwi Astharini ${ }^{1}$, Suci Rahmatia ${ }^{1}$, Tio Apridinata ${ }^{1}$, Raja P. Batubara ${ }^{1}$ \\ ${ }^{1}$ Program Studi Teknik Elektro, Fakultas Sains dan Teknologi, Universitas Al Azhar Indonesia, Kompleks \\ Masjid Agung Al Azhar, Jakarta Selatan, 12110, Indonesia \\ Email: astharini@uai.ac.id
}

\begin{abstract}
Abstrak - Tulisan ini melaporkan pengembangan perangkat untuk pendeteksian adanya api dan menentukan arah lokasi api. Lokasi titik api dinyatakan jarak relatif terhadap sensor. Penelitian dibatasi untuk menentukan lokasi titik api pada ruangan tertutup, di mana suhu ruangan lebih terkendali dan diharapkan tidak terpengaruh pengaruh lingkungan seperti cuaca. Perangkat yang dikembangkan menggunakan sistem minimum berbasis mikrokontroler ATMega16, memanfaatkan sensor panas array TPA81 dan display LCD. Sistem telah mampu mendeteksi dan menentukan lokasi lilin pada radius $0,5 \mathrm{~m} 180$ derajat.
\end{abstract}

Abstract - This paper reports the development of a fire detection detection device for closed room. The device detects and locates the present of fire in a room. Location of fire or heatsource is defined as relative distance to the sensor. The development was limited for usage within closed room with normally controlled temperature. The device was developed using a minimum system on microcontroller ATMega16, array heat sensor TPA81 and LCD display. The prototype introduced was firmly successful in detecting and locating a single candle within $0.5 \mathrm{~m}$ distance and 180 degree angle scope, assuming the device to be planted on a wall in a room.

Keywords - Fire detection, minimum system, heat sensor array

\section{PENDAHULUAN}

$\mathrm{K}$ ebakaran bangunan umum adalah salah satu bahaya pada lingkungan perkotaan. Berbeda dengan kebakaran rumah yang paling banyak disebabkan oleh kecelakaan di lingkungan dapur, banyak kebakaran gedung disebabkan masalah kelistrikan, dalam instalasi ataupun pada perangkat elektronik. Kebakaran semacam ini dimulai pada tingkat yang relatif kecil, namun dapat membahayakan gedung yang besar sekalipun. Resiko yang tinggi terutama dihadapi oleh gedung atau bangunan dengan fungsi khusus seperti adanya penggunaan bahan kimia, atau perangkat elektronik dalam jumlah besar.

Salah satu aspek keamanan dalam gedung modern saat ini penanganan bahaya kebakaran. Sistem keamanan yang umum digunakan pada saat ini berbasis pada deteksi asap dan alarm. Namun pengembangan juga dilakukan menuju pada pemadaman kebakaran otomatis, atau autonomous fire fighting. Hal ini dapat dilakukan melalui pengaturan cerdas pada sistem penyemprotan gedung (sprinkler) yang sudah ada, maupun secara lebih agresif dengan memfungsikan perangkat bergerak yang memadamkan api pada titik tertentu (fire fighting robot). Kedua pendekatan di atas mendasarkan aksi pada informasi lokasi titik api.

Pada tulisan ini perangkat yang dikembangkan mendeteksi adanya api dan menentukan arah lokasi titik api pada ruangan, semenjak api masih kecil.

Hasil penelitian dapat memberikan informasi untuk peringatan dini yang diharapkan berkontribusi memperkecil kerusakan dan korban. Lebih lanjut hasil penelitian ini dapat dikembangkan untuk membangun alat pemadam otomatis, sesuai lokasi dan besarnya api.

Pada bagian setelah ini tulisan disusun sebagai berikut. Bagian kedua menampilkan tinjauan pustaka untuk penelitian, bagian ketiga mengenai metode pengerjaan, bagian keempat menjabarkan 
implementasi dan pembahasan, dan ditutup dengan kesimpulan pada bagian terakhir.

\section{TINJAUAN PUSTAKA}

Pustaka yang digunakan mencakup tulisan mengenai sistem pemadam api cerdas, robot pemadam api, risiko kebakaran gedung, dan penggunaan ultraviolet untuk sensor api.

Pustaka [1] mengembangkan suatu robot pemadam api yang menggunakan 4 macam sensor, dan komunikasi nir kabel. Untuk deteksi sumber api digunakan 2 flame sensor dan aturan multi sensor, untuk menentukan lokasi relatif titik api terhadap robot. Pustaka [2] dan [3] mengembangkan sistem pemadam api autonomus sebagai bagian dari bangunan cerdas. Pada [2] digunakan sensor UV untuk menentukan arah sumber api pada area $5 \mathrm{~m}$. Pada [3] dihasilkan sistem yang mampu mendeteksi dan memadamkan sumber api kecil dalam waktu 5 detik, menggunakan sensor panas thermopile array untuk menentukan lokasi titik api pada jarak 1,38,7 m. Pustaka [4] adalah tesis magister yang memberi masukan mengenai pengawasan dan penanganan kebakaran pada gedung. Di antara data yang ditunjukkan adalah bahwa deteksi dini dapat menurunkan resiko kebakaran gedung sampai dengan 67\%. Pustaka [5] memberi gambaran pemanfaatan ultra violet untuk menentukan lokasi api (flame sensor).

\section{METODE PENGEMBANGAN}

Prototipe yang dikembangkan dalam penelitian ini mendeteksi adanya api atau sumber panas dalam ruangan, berikut mengestimasi posisi atau arah titik api dan jaraknya dari sensor. Penelitian dibatasi untuk menentukan lokasi titik api dalam ruangan tertutup, di mana suhu ruangan lebih terkendali dan diasumsikan tidak terpengaruh lingkungan seperti cuaca.

Kerja sistem dibagi atas tiga fungsi, yaitu penentuan adanya api; penentuan arah dan jarak titik api dari perangkat; display dan peringatan. Untuk itu sistem yang dikembangkan terdiri atas dua bagian utama yaitu sensor panas, dan pengolah data. Pengolah data disini dapat menggunakan laptop, ataupun mikrokontroler. Pada pengembangan ini digunakan sistem minimum dengan mikrokontroler.
Tahapan pekerjaan yang dilakukan dalam penelitian ini digambarkan dalam diagram alur pada Gambar 1.

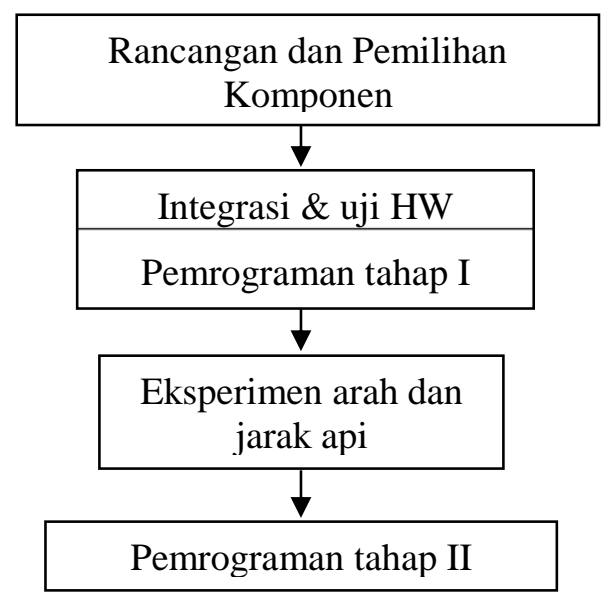

Gambar 1. Diagram Alur Penelitian

\section{HASIL DAN PEMBAHASAN}

Pada bagian ini akan dibahas pekerjaan yang dilakukan sesuai tahapan yang dipaparkan di atas.

\section{Perancangan dan Pemilihan Komponen}

Pada latar belakang disampaikan arahan penelitian adalah sistem pendeteksi api untuk digunakan pada ruangan secara umum, namun pengembangan prototipe yang sesuai membutuhkan pengujian yang layak. Dengan alasan keselamatan dan keterbatasan ruang eksperimen, maka pada penelitian ini akan digunakan sumber panas skala kecil, yaitu api lilin dan solder.

Salah satu implikasi batasan sumber panas di atas adalah bahwa energi panas yang terdisipasi tidak terlalu besar. Hal ini mempengaruhi pemilihan sensor, dan juga pada pemrograman penentuan jarak dan arah api.

Untuk mendeteksi panas digunakan sensor panas array 8x1 TPA81. Merupakan kumpulan 8 sensor panas yang difungsikan dalam array, sensor ini adalah non pada dasarnya adalah thermocouple yang mendeteksi suhu udara, atau non-contact temperature sensor. Sensor ini dapat dengan baik mendeteksi api lilin pada jarak $2 \mathrm{~m}$.

Dalam sistem yang digunakan, sensor ini langsung terhubung dengan pengendali mikrokontroler Atmega 16. Data dari sensor kemudian ditampilkan pada display LCD. Sesuai yang disampaikan pada 
proposal, untuk pengolah data digunakan prosesor yang sudah tersedia di Laboratorium Teknik Elektro UAI. Saat ini Lab Elektro UAI memiliki beberapa mikrokontroler yang digunakan untuk keperluan praktikum, pelatihan dan penelitian. Beberapa di antaranya juga biasa digunakan dengan LCD display. Mikrokontroler yang digunakan yaitu ATMega16 dipilih karena tersedia di laboratorium sehingga tidak memerlukan pengadaan tersendiri, dan dibandingkan dengan prosesor lain yang tersedia di lab dinilai paling memadai secara kapasitas untuk penggunaan penelitian ini. Beberapa mikrokontroler lain yang tersedia ada yang memiliki kapasitas yang lebih besar maupun lebih kecil.

\section{Integrasi Hardware}

Seluruh bagian elektronik pada tulisan ini dirancang dan dibuat sendiri dalam pengerjaan menggunakan fasilitas Laboratorium Teknik Elektro UAI.

Secara perangkat keras, sistem yang dibangun terdiri atas tiga komponen terpisah, yaitu sensor, mikrokontroler, dan display. Gambar 2 menunjukkan hubungan ketiga komponen tersebut dan aliran informasinya. Implementasi perangkat keras dilakukan berdasarkan perancangan yang dibuat. Gambar 3 menampilkan diagram skematik untuk perangkat.

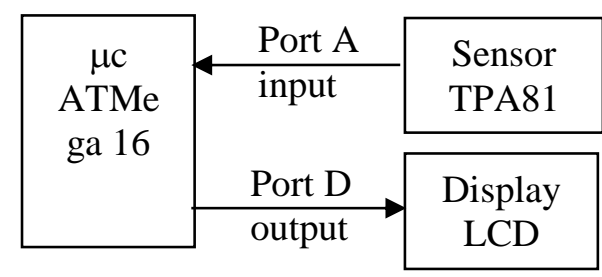

Gambar 2. Diagram blok perangkat keras
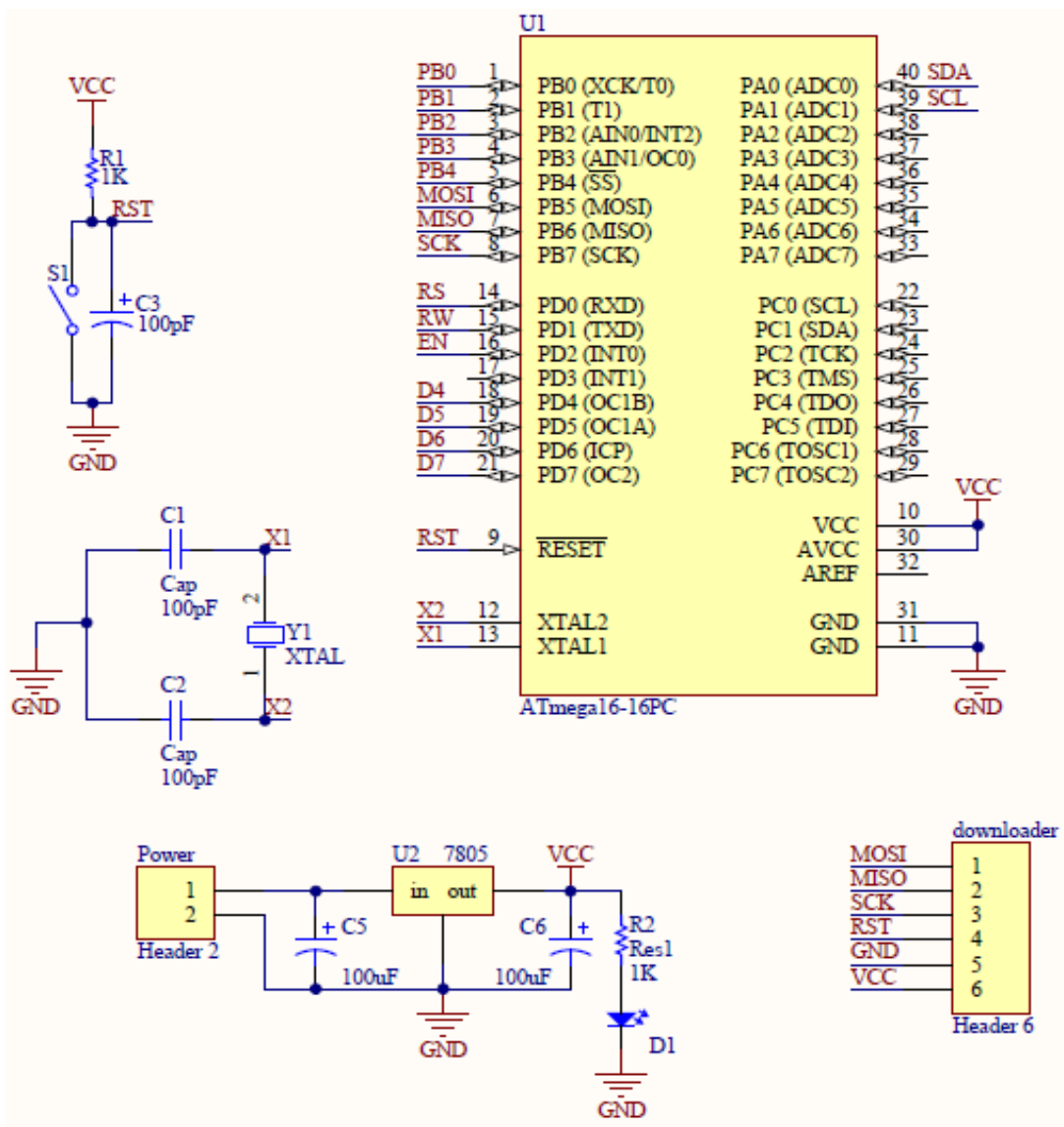

Gambar 3. Diagram skematik perangkat keras
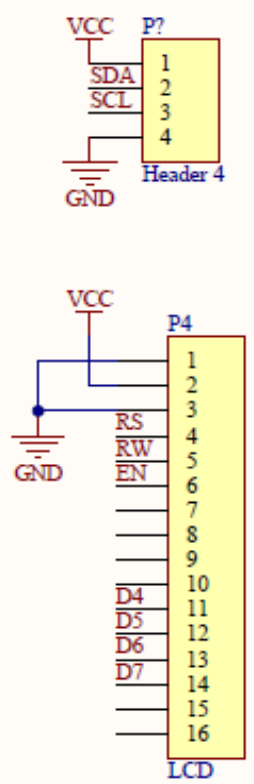


\section{Uji Perangkat}

Pengujian di sini dilakukan untuk memastikan bahwa sensor beserta perangkat keseluruhan telah bekerja sesuai yang diharapkan. Di sini juga diamati bagaimana sistem merespon perubahan lingkungannya.

Sesuai tujuan dasarnya, maka pengujian sistem sensor diilakukan untuk memastikan bahwa sistem dapat mendeteksi adanya api atau dalam hal ini perubahan panas. Karena itu data ditampilkan dalam dua kategori, yaitu saat keadaan normal dan saat terdapat sumber panas.

Untuk masing-masing tipe data dilakukan sejumlah pengamatan, (tabel 1) ditampilkan 4 seri data per tipe, mewakili pengamatan-pengamatan pada uji perangkat.

Tabel 1. Uji Perangkat

\begin{tabular}{lcccccccc}
\hline Lingk & \multicolumn{8}{c}{ Array sensor 8x1 } \\
\cline { 2 - 9 } ungan & $\mathbf{1}$ & $\mathbf{2}$ & $\mathbf{3}$ & $\mathbf{4}$ & $\mathbf{5}$ & $\mathbf{6}$ & $\mathbf{7}$ & $\mathbf{8}$ \\
\hline Normal & 25 & 27 & 27 & 27 & 29 & 27 & 27 & 28 \\
, Tanpa & 25 & 28 & 28 & 28 & 27 & 27 & 28 & 28 \\
sumber & 26 & 28 & 27 & 28 & 29 & 26 & 27 & 29 \\
panas & 26 & 28 & 28 & 28 & 29 & 27 & 30 & 31 \\
& 72 & 154 & 151 & 119 & 75 & 53 & 49 & 47 \\
Ada & 31 & 36 & 62 & 86 & 44 & 41 & 40 & 39 \\
sumber & 38 & 40 & 40 & 104 & 148 & 154 & 80 & 57 \\
panas & 159 & 153 & 151 & 149 & 149 & 151 & 159 & 131 \\
\hline
\end{tabular}

Dari data yang diamati dapat dilihat beberapa hal. Yang pertama adalah bahwa sensor telah berfungsi atau mampu menunjukkan adanya sumber panas pada ruangan secara signifikan. Lebih lanjut teramati bahwa dalam keadaan normal pun, sensor menunjukkan nilai yang berfluktuasi. Pada kondisi lapangan teramati bahwa ini di antaranya dapat diakibatkan oleh pergerakan personil dalam ruangan. Namun fluktuasi nilai ini dapat kita lihat masih dalam kisaran 10 derajat celsius dari suhu ruangan. Sedangkan saat sumber panas dihadirkan, sensor secara signifikan menampilkan nilai temperatur yang tinggi. Pada keempat seri data yang ditampiilkan dengan sumber panas, terlihat variasi nilai yang berbeda. Hal ini diamati merupakan efek dari jenis dan lokasi sumber panas. Untuk jenis sumber panas, pada pengujian ini digunakan ujung solder, yang posisinya mudah dirubah. Untuk lokasi teramati bahwa sensor telah sukses menampilkan variasi nilai bukan hanya berdasar jarak jauh sumber panas terhadap panel sensor, tapi juga arah sumber juga ditampilkan dalam variasi seri data.
Selanjutnya hasil uji perangkat ini manjadi dasar untuk melakukan eksperimen dan pengamatan selanjutnya.

\section{Pemrograman Awal}

Pemrograman di sini hanya dilakukan untuk mengakomodasi eksperimen yang dilakukan pada tahap selanjutnya. Karena itu program yang diberikan pada mikrokontroler terdiri atas: inisialisasi, pembacaan data sensor, dan display.

Inisialisasi termasuk di dalamnya inisialisasi Port A untuk sensor dan Port D untuk LCD display. Pembacaan data di sini dilakukan dari 8 sensor pada TPA81 array. Pembacaan dilakukan secara serial, dengan pengiriman setiap 40 detik. Display data pada LCD menampilkan data temperatur hasil pengukuran kedelapan sensor ditampilkan dalam 2 baris pada LCD Display.

\section{Eksperimen Jarak dan Arah Api}

Eksperimen pada bagian ini dirancang untuk melihat bagaimana reaksi sensor terhadap sumber api pada lokasi yang bervariasi. Eksperimen dilakukan menggunakan lilin sebagai sumber panas, berbeda dengan pada pengujian awal terhadap perangkat yang menggunakan solder. Hal ini karena lilin lebih stabil posisinya dan dapat diletakkan dengan jarak terukur yang ditentukan. Gambar 4 berikut menunjukkan skenario pengambilan data yang telah dilakukan.

Eksperimen dilakukan dengan menempatkan titik api lilin pada tegak lurus di depan sensor, pada jarak yang divariasikan dari $10 \mathrm{~cm}$ sampai $2 \mathrm{~m}$. Hal ini dilakukan berulang untuk memperoleh validitas data yang dicatat. Hasil yang ditampilkan adalah rerata nilai yang teramati (Tabel 2). Eksperimen yang telah dilakukan baru sampai pada jarak $50 \mathrm{~cm}$.

Dari tabel eksperimen dapat dilihat bahwa masingmasing dari kedelapan sensor menampilkan pengukuran yang berbeda, pada setiap kejadian. Pada ketiga skenario jarak, sensor 4 selalu menunjukkan pembacaan temperatur yang paling tinggi, dan suhu cenderung semakin menurun sejalan nomor sensor 3-2-1 maupun 5-6-7-8. Hal ini berhubungan dengan peletakkan sumber panas, yang dalam hal ini adalah tepat atau tegak lurus di depan sensor. Data ini menunjukkan bahwa pembacaan masing-masing sensor pada array $8 \times 1$ bergantung pada jarak sensor secara individu terhadap sumbernya. 


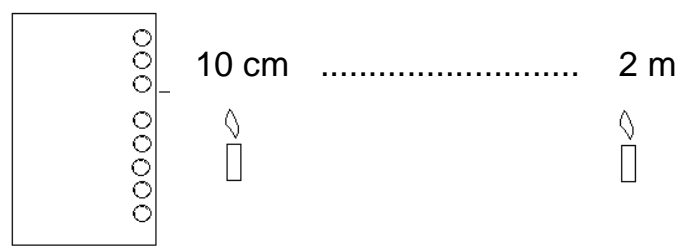

Gambar 4.Skenario Eksperimen

Tabel 2. Eksperimen Jarak Api

\begin{tabular}{lcccccccc}
\hline $\begin{array}{l}\text { Jarak } \\
\text { sumber } \\
\text { panas }\end{array}$ & $\mathbf{1}$ & $\mathbf{2}$ & $\mathbf{3}$ & $\mathbf{4}$ & $\mathbf{5}$ & $\mathbf{6}$ & $\mathbf{7}$ & $\mathbf{8}$ \\
\hline $10 \mathrm{~cm}$ & 33 & 44 & 135 & 149 & 55 & 32 & 34 & 31 \\
$30 \mathrm{~cm}$ & 28 & 30 & 45 & 130 & 33 & 28 & 29 & 28 \\
$50 \mathrm{~cm}$ & 26 & 28 & 30 & 95 & 31 & 26 & 26 & 33 \\
\hline
\end{tabular}

Analisa

Setelah pengamatan dilakukan Pemrograman berdasarkan analisa hasil pengamatan pada eksperimen. Beberapa hal telah dicatat dan secara bertahap diimplementasikan pada algoritma dan progpam. Hal-hal penting yang digunakan pada algoritma program disampaikan berikut ini.

Adanya titik api ditandai oleh peningkatan suhu di atas $50^{\circ} \mathrm{C}$, pada satu atau lebih sensor dalam array.. Suhu tertinggi pada array digunakan untuk memperkirakan jarak titik api dengan panel sensor. Suhu $>140^{\circ} \mathrm{C}$ menunjukkan jarak $10 \mathrm{~cm}$. Suhu $120-$ $140^{\circ} \mathrm{C}$ menunjukkan kisaran jarak $30 \mathrm{~cm}$. Suhu 90 $120^{\circ} \mathrm{C}$ menunjukkan jarak pada kisaran $50 \mathrm{~cm}$.

Sensor mana pada array yang menunjukkan nilai tertinggi menentukan arah atau lokasi relatif titik api terhadap panel sensor.

\section{KESIMPULAN DAN SARAN}

Penelitian ini telah mengembangkan perangkat berbasis mikrokontroler yang mengantisipasi api pada ruangan tertutup.

Prototipe yang dikembangkan dalam penelitian ini mendeteksi adanya api atau sumber panas dalam ruangan, berikut memprediksi posisi atau arah titik api dan jaraknya dari sensor. Sistem yang dikembangkan menggunakan sistem minimum berbasis mikrokontroler ATMega16, memanfaatkan sensor panas array TPA81 dan display LCD. Atas alasan keamanan penelitian dibatasi pada sumber api lilin dan jarak kurang dari $2 \mathrm{~m}$.
Perangkat secara konsisten telah dapat mendeteksi panas lilin sampai jarak $50 \mathrm{~cm}$. Melalui array sensor juga telah dapat dilihat lokasi titik api sebagai arah relatif (kanan, kiri, depan) terhadap panel sensor.

Array sensor yang diimplementasi berupa satu baris horisontal berisi 8 sensor suhu. Tipe ini cocok untuk penggunaan sensor/perangkat diam yang ditempatkan pada misalnya dinding ruangan. Jika yang diinginkan adalah perangkat bergerak seperti pada robot, array sensor akan lebih baik jika disusun dalam bentuk lingkaran, atau dapat juga menggunakan matriks 2 baris sensor. Penyusunan seperti ini dapat memperluas daerah deteksi menjadi $360^{\circ}$.

Untuk rancangan program yang lebih baik, pengamatan perlu diperluas dengan eksperimen menggunakan sumber api yang lebih besar, sehingga dapat dideteksi pada jarak yang lebih jauh.

\section{UCAPAN TERIMA KASIH}

Peneliti mengucapkan terima kasih kepada LP2M UAI atas pendanaan kegiatan Grant Research tahun 2013 sehingga hasil penelitian ini dapat terpublikasi.

\section{DAFTAR PUSTAKA}

[1] TL. Chien, Jr H. Guo, KL. Su, SV. Shiau; M.A. Wickert; Develop a Multiple Interface Based Fire Fighting Robot; Proceedings of International Conference on Mechatronics; 2007.

[2] G. Hu, Z. Li; Design of Intelligent Fire Extinguishing System of Interior Large Space; International Conference on E-Product E-Service and E-Entertainment ICEEE; 2010.

[3] R. Masood, A. Shahbaz, S. Maqsood, Imran \& Pasha; Autonomous fire extinguishing system ; International Conference on Robotics and Artificial Intelligence ICRAI, 2012.

[4] Muhadi; Pencegahan Resiko Kebakaran Gedung: Peran dan Tindakan Pusat Layanan Kebakaran dan Pertolongan Departement Rhone; Tesis Magister Teknik Pembangunan Wilayah dan Kota Universitas Diponegoro, 2008.

[5] A.R. Pauchard; D. Manic; A. Flanagan; P.A Besse.; R.S. Popovic; A method for spark rejection in ultraviolet flame detectors ; IEEE Transactions on Industrial Electronics, Volume: 47 Issue: 1; 2000.

[6] JG. Webster; The measurement, instrumentation, and sensors handbook; 1999. 